\title{
Assessing Microbial Communities Related to Mercury Transformations in Contaminated Streambank Soils
}

\author{
Yazeed Abdelmageed $\mathbb{D} \cdot$ Carrie Miller • \\ Carrie Sanders • Timothy Egbo • Alexander Johs $\mathbb{D} \cdot$ \\ Boakai Robertson
}

Received: 27 July 2020 / Accepted: 28 December 2020 / Published online: 13 January 2021

(C) The Author(s) 2021

\begin{abstract}
In nature, the bioaccumulative potent neurotoxin methylmercury $(\mathrm{MeHg})$ is produced from inorganic mercury $(\mathrm{Hg})$ predominantly by anaerobic microorganisms. Hg-contaminated soils are a potential source of $\mathrm{MeHg}$ due to microbial activity. We examine streambank soils collected from the contaminated East Fork Poplar Creek (EFPC) in Tennessee, USA, where seasonal variations in MeHg levels have been observed throughout the year, suggesting active microbial $\mathrm{Hg}$ methylation. In this study, we characterized the microbial community in contaminated bank soil samples collected from two locations over a period of one year and compared the results to soil samples from an uncontaminated reference site with
\end{abstract}

Notice: This manuscript has been authored by UT-Battelle, LLC, under contract DE-AC05-00OR22725 with the US Department of Energy (DOE). The US government retains and the publisher, by accepting the article for publication, acknowledges that the US government retains a nonexclusive, paid-up, irrevocable, worldwide license to publish or reproduce the published form of this manuscript, or allow others to do so, for US government purposes. DOE will provide public access to these results of federally sponsored research in accordance with the DOE Public Access Plan (http://energy.gov/downloads/doe-public-access-plan).

Y. Abdelmageed $(\varangle) \cdot$ C. Sanders $\cdot$ T. Egbo $\cdot$ B. Robertson Microbiology Program, Department of Biological Sciences, Alabama State University, Montgomery, AL 36104, USA

e-mail: yelsarrag@gmail.com

C. Miller

Ramapo College of New Jersey, Mahwah, NJ 07430, USA

A. Johs

Environmental Sciences Division, Oak Ridge National

Laboratory, Oak Ridge, TN 37831, USA similar geochemistry $(n=12)$. Microbial community composition and diversity were assessed by $16 \mathrm{~S}$ rRNA gene amplicon sequencing. Furthermore, to isolate potential methylators from soils, enrichment cultures were prepared using selective media. A set of three cladespecific primers targeting the gene $h g c A$ were used to detect $\mathrm{Hg}$ methylators among the $\delta$-Proteobacteria in EFPC bank soils across all seasons. Two families among the $\delta$-Proteobacteria that have been previously associated with $\mathrm{Hg}$ methylation, Geobacteraceae and Syntrophobacteraceae, were found to be predominant with relative abundances of $0.13 \%$ and $4.0 \%$, respectively. However, in soil enrichment cultures, Firmicutes were predominant among families associated with $\mathrm{Hg}$ methylation. Specifically, Clostridiaceae and Peptococcaceae and their genera Clostridium and Desulfosporosinus were among the ten most abundant genera with relative abundances of $2.6 \%$ and $1.7 \%$, respectively. These results offer insights into the role of microbial communities on $\mathrm{Hg}$ transformation processes in contaminated bank soils in EFPC. Identifying the biogeochemical drivers of $\mathrm{MeHg}$ production is critical for future remediation efforts.

Keywords Methylmercury · Mercury methylation . Geochemistry $\cdot$ Deltaproteobacteria $\cdot$ Clostridia

\section{Introduction}

The Oak Ridge Reservation (ORR) of the US Department of Energy in East Tennessee, USA, was established during World War II for nuclear weapons 
development. During the 1950s and 1960s, the Y-12 National Security Complex (Y-12) located at the headwaters of East Fork Poplar Creek (EFPC) used elemental mercury $(\mathrm{Hg})$ to separate lithium isotopes using a Li$\mathrm{Hg}$ amalgamation process at industrial scales. EFPC originates within the Hg-contaminated subsurface storm drain network of Y-12 and discharges process water directly into the stream (Brooks and Southworth 2011; Turner and Southworth 1999; Donovan et al. 2014). Historical records indicate that a total of approximately 350 tons of elemental $\mathrm{Hg}$ were lost to the environment during the mid of the last century, contaminating soils, groundwater, air, and EFPC (Brooks and Southworth 2011). Also, Hg migration from the source areas via atmospheric deposition, surface water runoff, sediment, and groundwater transport contaminated the upper (U) and lower (L) EFPC ecosystem (Donovan et al. 2014). The bank and floodplain soils of EFPC were found to contain high concentrations of $\mathrm{Hg}$, reaching up to $3000 \mu \mathrm{g} / \mathrm{g}$ in various physicochemical forms (Barnett et al. 1997; Barnett and Turner 1995; Harris et al. 1996), with insoluble mercuric sulfide as the predominant species (Revis et al. 1989).

Despite extensive remediation efforts in UEFPC and around the Y-12 plant that led to an $85 \%$ decrease in total Hg (THg) flux, more recent studies identified soils with high $\mathrm{Hg}$ concentrations downstream along the banks of LEFPC (Southworth et al. 2010; Southworth et al. 2013). Contaminated bank soils at sites with little to no past remediation activities represent new point sources of $\mathrm{Hg}$ entering EFPC locally and downstream (Southworth et al. 2010; Southworth et al. 2013). Methylmercury $(\mathrm{MeHg}$ ) concentrations increase from upstream to downstream locations as a result of instream methylation by periphyton and other biological activity (Watson et al. 2016). Recent modeling studies linked the highest $\mathrm{Hg}$ fluxes into the EFPC ecosystem with streambank erosion and streambed sediment resuspension during storm events (Watson et al. 2016; Ketelle et al. 2017). The estimated annual fluxes of $\mathrm{Hg}$ and $\mathrm{MeHg}$ due to streambank erosion for all LEFPC are estimated to be $38.6 \mathrm{~kg}$ and $0.0056 \mathrm{~kg}$, respectively (Ketelle et al. 2017), while $5.4 \mathrm{~km}$ downstream from Y-12 the estimated annual fluxes were $98 \mathrm{~kg}$ of $\mathrm{Hg}$ and $0.085 \mathrm{~kg}$ of $\mathrm{MeHg}$ (Riscassi et al. 2016). Therefore, $\mathrm{MeHg}$ concentrations in water and especially in fish have not declined in response to improvements in water quality and have shown increasing trends in some cases (Brooks and Southworth 2011).
Inorganic $\mathrm{Hg}$ species can be transformed into the more toxic organic $\mathrm{MeHg}$ predominantly by anaerobic microorganisms (Hintelmann 2010; Gilmour et al. 2013). Mercury methylation has been attributed mainly to sulfate-reducing bacteria (SRB) (Pak and Bartha 1998; Achá et al. 2011; Achá et al. 2012; Bravo et al. 2016), iron-reducing bacteria (IRB) (Fleming et al. 2006; Bravo et al. 2015), methanogens (Hamelin et al. 2011), and syntrophs (Bae et al. 2014). Two genes, $h g c A$ and $h g c B$, were found to be essential for microbial $\mathrm{Hg}$ methylation in bacteria and archaea. They encode a putative corrinoid protein, $\mathrm{HgcA}$, and a $2[4 \mathrm{Fe}-4 \mathrm{~S}]$ ferredoxin $\mathrm{HgcB}$, each of which was proposed to act as methyl and electron donor, respectively, which are required for the conversion of $\mathrm{Hg}^{2+}$ to $\mathrm{CH} 3 \mathrm{Hg}^{+}$(Parks et al. 2013). Sequence analysis of HgcA orthologs in all confirmed and predicted methylators revealed a highly conserved motif characterized by the amino acid sequence, N(V/I)WCA(A/G)GK, and a set of four to five C-terminal transmembrane helices (Parks et al. 2013). Degenerate PCR primers were developed to detect microorganisms carrying $h_{g c A B}$ genes in diverse environments. These primers showed reliable results for most strains carrying $\operatorname{hgcAB}$ among the three major $\mathrm{Hg}$ methylating clades, Deltaproteobacteria, Clostridia, and Euryarchaeota (Christensen et al. 2016).

While several studies have been conducted to characterize the microbial community structure in EFPC sediments (Christensen et al. 2018; Vishnivetskaya et al. 2011), none has examined the influence of $\mathrm{Hg}$ contamination on the prevalence of $\mathrm{Hg}$ methylators in streambank soils. In the present study, we collected EFPC streambank soils at two locations with different $\mathrm{Hg}$ levels and determined microbial community compositions using 16S rRNA gene amplicon sequencing. Furthermore, we used three sets of clade-specific primers targeting $h g c \mathrm{~A}$ as a biomarker for $\mathrm{Hg}$ methylation and compared the results to an uncontaminated reference site with similar geochemistry.

\section{Materials and Methods}

\subsection{Soil Sampling and Analysis}

Streambank soil samples were collected from EFPC at two locations over a period of one year (fall 2016summer 2017). The sampling locations were designated as EFK 18.2, and EFK 11.2, where the number indicates 
the stream distance in kilometers (East Fork kilometer), from the mouth of the creek (Fig. 1). Bank soils sampled at EFK $18.2(36.00438 \mathrm{~N}, 84.28246 \mathrm{~W})$ were collected from a dark-colored soil layer containing high $\mathrm{Hg}$ concentrations associated with the presence of coal fines, which has been designated as the historical release deposit (HRD) (Southworth et al. 2010; Southworth et al. 2013). EFK $11.2(35.982243 \mathrm{~N}, 84.32755 \mathrm{~W})$ is located further downstream and represents a section of streambank soils with lower $\mathrm{Hg}$ contamination levels. Hg-contaminated bank soil samples collected in all seasons were compared to bank soil samples from an uncontaminated reference site, Hinds Creek (HC), which is located $25 \mathrm{~km}$ northeast of Y-12 near Clinton, TN, USA (36.140842 N, 84.051302 W). Bank soil samples were placed into sterile plastic sampling bags (Whirl-Pak, Nasco, Fort Atkinson, WI) and transported on dry ice to Alabama State University within $24 \mathrm{~h}$, homogenized, and kept at $-20{ }^{\circ} \mathrm{C}$ until analysis. Soil temperature, $\mathrm{pH}$, and other geochemical parameters, including $\mathrm{C}, \mathrm{S}, \mathrm{Fe}$, and soil particle size analysis, were determined according to standard methods and are reported elsewhere (Egbo et al. 2017; Dickson et al. 2019). A 10-g (wet weight) subsample was taken from all samples $(n=12)$, placed in acidwashed and sterilized glass vials, and shipped overnight on dry ice to Brooks Applied Labs (Bothell, WA) for $\mathrm{THg}$ and $\mathrm{MeHg}$ analyses. Samples were prepared and analyzed following USEPA Method 1631 for THg and a modified USEPA Method 1630 for MeHg.

\subsection{Bacterial Community Composition}

Community genomic DNA (gDNA) was extracted in triplicate from $1 \mathrm{~g}$ (dry weight) of soil using a PowerSoil DNA isolation kit (QIAGEN, Germantown, MD) following the manufacturer's instructions. The gDNA was purified $(n=36)$ using a DNA purification kit (Promega, Madison, WI), and the quality and concentration were measured with a NanoDrop 2000c spectrophotometer (Thermo Scientific, Waltham, MA). Extracted DNA from streambank soils and enrichment cultures were shipped in a dry ice container to the University of Alabama at Birmingham Microbiome Resource (UAB, Birmingham, AL) for 16S rRNA amplicon sequencing, as previously described in detail (Kumar et al. 2014). Briefly, the barcoded primers 515F and 806R targeting the V4 region of the 16S rRNA gene were used for PCR amplification. The PCR protocol used was as follows: 1 cycle of preincubation at $94{ }^{\circ} \mathrm{C}$ for $1 \mathrm{~min}$, followed by 32 cycles of denaturation at $94^{\circ} \mathrm{C}$ for $30 \mathrm{~s}$, annealing at $50{ }^{\circ} \mathrm{C}$ for $1 \mathrm{~min}$, and extension at $65^{\circ} \mathrm{C}$ for $1 \mathrm{~min}$, then 1 cycle of final incubation for $3 \mathrm{~min}$ at $65{ }^{\circ} \mathrm{C}$. PCR products were resolved on agarose gels, isolated, and purified using Qiagen kits and quantitated prior to sequencing at the UAB Genomic Core Facility. Each sample was run in duplicate, and the amplicons were sequenced on the Illumina MiSeq platform. 16S rRNA gene amplicon data were processed using the microbiome analysis pipeline (QWRAP) at UAB

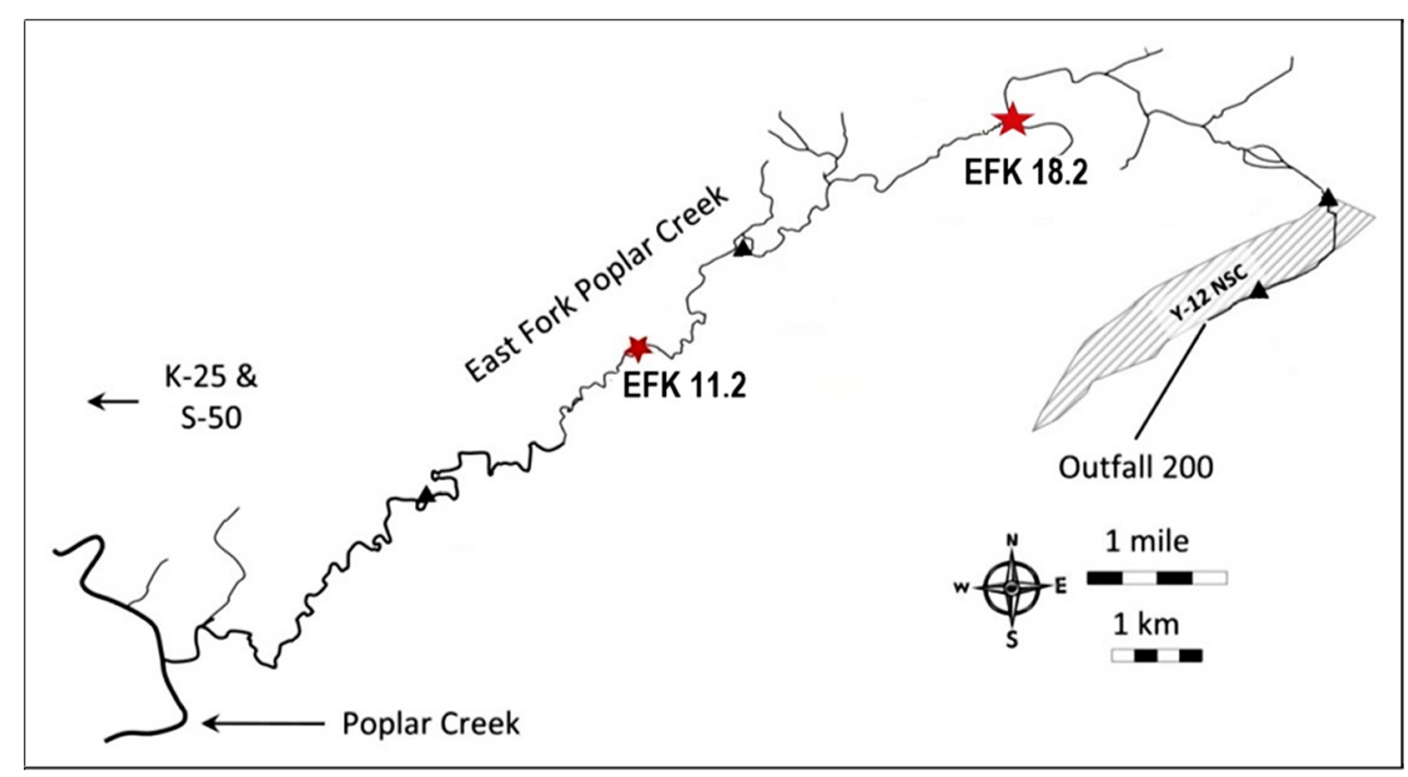

Fig. 1 EFPC streambank soil sampling locations (ELSEVIER LICENSE NUMBER: 4864400393068) 
(Kozich et al. 2013; Kumar et al. 2014). A combination of tools within the QIIME pipeline were utilized for clustering reads into operational taxonomic units (uclust), taxon assignment (RDP classifier using the Greengenes 16S rDNA database (McDonald et al. 2012; Wang et al. 2007). Operational taxonomic units (OTUs) were clustered at $97 \%$ pairwise identity. For result reporting, QWRAP generates a static HTML report. The output includes the percentages of OTUs down to genus and species level and alpha and beta diversity using different metrics. Filtered lists of top 10,25 , and 100 OTUs and taxa were also generated.

\subsection{Enrichment Cultures}

Here, the intent was to compare the $\mathrm{Hg}$ methylationrelevant microbial abundance in the soil samples of the studied sites in all seasons under similar growth conditions based on their existence and persistence in these samples. All soil samples were grown in triplicate under optimum conditions, and the extracted DNAs were pooled and assigned identification codes based on site and season (108 total). One gram of streambank soils $(n=12)$ was used for enrichment cultures in three different selective media (described below). Soils were placed in $10 \mathrm{ml}$ of media in Hungate tubes and incubated at $30{ }^{\circ} \mathrm{C}$ or $37{ }^{\circ} \mathrm{C}$ for two weeks under anoxic conditions. The bottom $2 \mathrm{ml}$ of the media and the settled soil samples were taken separately for DNA extraction. The UltraClean Microbial DNA and the PowerSoil DNA extraction kits (QIAGEN, Germantown, MD) were used for DNA extraction from the enrichment culture media and settled soil, respectively, following the manufacturer's instructions. Extracted DNAs were used for 16S rRNA gene amplicon sequencing, as described above, and termed enrichment cultures.

Three different media were used for soil enrichment; mineral salt medium (DCB-1 medium for syntrophs), nutrient broth (NB) basal salt medium (PCA medium for IRB), and sulfate-free modified minimal organic yeast (MOY) medium (Zane et al. 2010) (SRB medium). The mineral salt medium was previously described by Mohn and Tiedje (1991) and DeWeerd et al. (1990). Briefly, it contained $40 \mathrm{mM}$ pyruvate, $0.2 \mathrm{mM} \mathrm{Na} 2 \mathrm{~S} \cdot 9 \mathrm{H}_{2} \mathrm{O}$, $0.2 \mathrm{mM}$ 1-cysteine, $1 \mathrm{~g}$ yeast extract/1, and $10 \mathrm{ml} / 1$ of a vitamin solution as described by Wolin et al. (1963) plus $5 \mathrm{ml} / 1$ special vitamin solution prepared by adding $4 \mathrm{mg}$ 1,4-naphthoquinone, $10 \mathrm{mg}$ nicotinamide, $1 \mathrm{mg}$ thiamine, $1 \mathrm{mg}$ lipoic acid, $1 \mathrm{mg}$ hemin, to $100 \mathrm{ml}$ of $10 \mathrm{mM}$
HEPES. The gas-phase was $\mathrm{N}_{2}: \mathrm{CO}_{2}(80: 20 \%)$, and the $\mathrm{pH}$ was adjusted with $\mathrm{CO}_{2}$ to 7.3. The NB basal salt medium was prepared as previously described (Coppi et al. 2001; Lin et al. 2014) containing $20 \mathrm{mM}$ acetate as an electron donor, and $40 \mathrm{mM}$ fumarate as an electron acceptor at a final $\mathrm{pH}$ 6.8. The sulfate-free MOY medium was described by Zane et al. (2010), with the following modifications; $2 \mathrm{mM} \mathrm{NaH} \mathrm{PO}_{4}, 0.1 \mu \mathrm{M}$ nickel chloride instead of nickel sulfate, $40 \mathrm{mM}$ sodium pyruvate, and $40 \mathrm{mM}$ sodium fumarate. The $\mathrm{pH}$ was adjusted with $2 \mathrm{~N} \mathrm{NaOH}$ to 7.2.

All cultures were maintained under strictly anoxic conditions in an anaerobic workstation (Don Whitley Scientific Ltd., West Yorkshire, UK) using a gas mixture of $80 \% \mathrm{~N}_{2}$ and $10 \%$ each for $\mathrm{H}_{2}$ and $\mathrm{CO}_{2}$. Tubes with the mineral salt medium were incubated at $37^{\circ} \mathrm{C}$, while tubes with NB or modified MOY media were incubated at $30{ }^{\circ} \mathrm{C}$ for two weeks before DNA extraction.

\subsection{Identification of Hg-Methylating Bacteria}

Three pairs of strain-specific $h g c A$ primers for potential methylators developed at Oak Ridge National Laboratory (ORNL) were used to amplify the $h g c A$ target gene (Christensen et al. 2016). Primer pairs for $h g c A$ from two confirmed and one predicted methylator were purchased from Integrated DNA Technologies (Coralville, IA). For each primer pair of the target strains, gDNA obtained from the American Type Culture Collection (ATCC, Old Town Manassas, VA) was used as a positive control. These primers were developed according to the nucleotide sequences in conserved regions, including a highly conserved sequence motif common to all known $h g c A$ homologs with some level of degeneracy, which allows them to amplify multiple $h g c A$ variants. Forward and reverse primers were constructed based on $h g c A$ sequence information from Desulfovibrio desulfuricans ND132; F: 5'-GCCA ACTACAAGCTGACCTTC-3' R: 5'-CCCG CCGCGCACCAGACGT T-3', Geobacter sulfurreducens PCA; F: 5'-GCCAACTACAAGAT GAGCTAC-3' R: 5'-CCGG CGGCGCACCAGACA TT-3' and Desulfomonile tiedjei DCB-1; F: 5'-GCGA ATTACAAGATGA GTTTC-3' R: 5'-CCCGC TGCACACCAGACATT-3'. The GC-content of $\delta$ Proteobacteria is typically high and consequently higher melting temperatures are needed for amplification. Multiple experiments were performed evaluating different 
strategies to optimize PCR parameters, which included variation of annealing temperature, extension time, and primer concentration, to achieve amplification resulting in a single distinct band of PCR product at the expected size. Two PCR kits were used: Premix Taq (Ex Taq ${ }^{\mathrm{TM}}$ version 2.0 -TaKaRa-Clontech, Mountain View, CA) and Phusion High-Fidelity master mix (New England BioLabs, Ipswich, MA). The TaKaRa kit produced the expected product $(\sim 950 \mathrm{bp})$ with ND132-primers only in $25-\mu \mathrm{l}$ reaction tubes containing $12.5 \mu \mathrm{l}$ premix, $10.5 \mu \mathrm{l}$ primers mix $(0.5 \mu \mathrm{l}$ of each $10 \mu \mathrm{M}$ primer plus $9.5 \mu \mathrm{l}$ PCR-grade water), and $2 \mu \mathrm{l}$ template DNA (25$30 \mathrm{ng}$ total). The amplification was initiated in a BioRad T100 thermal cycler (Bio-Rad, Hercules, CA) with 1 cycle of preincubation at $95^{\circ} \mathrm{C}$ for $2 \mathrm{~min}$, followed by 5 cycles of denaturation twice as follows; $30 \mathrm{~s}$ at $95^{\circ} \mathrm{C}$, $30 \mathrm{~s}$ at $68^{\circ} \mathrm{C}$ or $70^{\circ} \mathrm{C}$ for each five-cycle run, then $1 \mathrm{~min}$ at $72{ }^{\circ} \mathrm{C}$, followed by 30 cycles of denaturation $\left(95^{\circ} \mathrm{C}\right.$ for $30 \mathrm{~s}$ ), annealing $\left(70{ }^{\circ} \mathrm{C}\right.$ for $30 \mathrm{~s}$ ), and extension ( $72{ }^{\circ} \mathrm{C}$ for $1 \mathrm{~min}$ ) followed by a final incubation step at $72{ }^{\circ} \mathrm{C}$ for $10 \mathrm{~min}$. The Phusion kit produced the expected product with PCA and DCB-1 primers in $25-\mu \mathrm{l}$ reaction tubes containing $6.5 \mu \mathrm{l}$ premix, $16.5 \mu \mathrm{l}$ primers mix $(0.5 \mu \mathrm{M}$ final conc. $)$, and $2 \mu$ template DNA (25 ng total). The amplification started with preincubation at $98{ }^{\circ} \mathrm{C}$ for $5 \mathrm{~min}$, followed by 30 cycles of denaturation at $98{ }^{\circ} \mathrm{C}$ for $30 \mathrm{~s}$, annealing for $30 \mathrm{~s}$ at $58^{\circ} \mathrm{C}(\mathrm{PCA})$ or $60^{\circ} \mathrm{C}$ (DCB-1), then extension at $72^{\circ} \mathrm{C}$ for $1 \mathrm{~min}$, and then final incubation at $72{ }^{\circ} \mathrm{C}$ for $10 \mathrm{~min}$. PCR products were resolved in $1 \%$ agarose gel at $80 \mathrm{~V}$ for $1 \mathrm{~h}$. Bands at the expected size ( 950 bp) and corresponding amplicons were recovered using a QIAquick Gel Extraction Kit (QIAGEN, Germantown, $\mathrm{MD}$ ) and sent for Sanger sequencing with the primers for both strands at the Heflin Genomics Center, University of Alabama at Birmingham or the Genomics \& Sequencing Laboratory, Auburn University. The software MacVector version 16.0.1 (MacVector Inc., Apex NC, USA) and the NCBI BLASTN tools (https://blast. ncbi.nlm. nih.gov/Blast.cgi) were used to perform a 6frame translation and sequence alignment with known $h g c A$ sequence for each strain.

\subsection{Statistical Analysis}

The objective of the statistical analysis was to compare microbial abundance percentages to evaluate seasonalor site-related differences and whether the differences among levels of one factor were similar across levels of the other factor. Thus, the study was analyzed as a $4 \times 3$ factorial design with analysis of variance. This design requires that the residuals be normally distributed with equal variance. Typically, response variables that are measured as percentages violate one or both assumptions. Initial analyses explored the use of square root and arcsine transformations. Because the results of these tests were not drastically different from untransformed data, only results from the untransformed data are presented here.

The MIXED procedure of SAS 9.4 (SAS Institute, Inc., Cary, NC) was used to perform the analysis of variance. Least square means and standard errors were calculated by the level of the two factors and their interactions. When the interaction was declared significant from the omnibus F test, the SLICE option was used to perform a partitioned analysis of the interaction least square means or, in other words, an analysis of simple effects was performed. When no interaction was detected, and the omnibus $\mathrm{F}$ test indicated differences among levels of a factor, a comparison of mean differences was conducted using Tukey's (Tukey 1949) adjustment. Letter groupings were facilitated using a macro provided by Arnold Saxton (Saxton 1998). The level of significance for all analyses was set at 0.05 .

\section{Results}

\subsection{Variability of $\mathrm{Hg}$ and $\mathrm{MeHg}$ Between Sampling Sites}

The relationships between total $\mathrm{Hg}, \mathrm{MeHg}$, geochemistry, and seasonal variations were explored. Temperature, redox conditions, and $\mathrm{pH}$ influence the activity of potential methylators and $\mathrm{Hg}$ methylation potential. The physicochemical characteristics of EFPC streambank soils and $\mathrm{Hg}$ levels vary between upstream and downstream locations. A previous study reported the soil composition and geochemistry of the streambank soils at the sampling sites (Dickson et al. 2017). An analysis of the soil particle size distributions showed that EFPC bank soils can be classified as silty clay loam with more silt and clay contents at EFK 11.2 (Table 1). Elemental analyses showed $\mathrm{Cu}, \mathrm{Mn}, \mathrm{Mg}, \mathrm{Zn}, \mathrm{S}$, and others were at levels of less than $1 \%$ of the dried soils, while $\mathrm{Ca}, \mathrm{K}, \mathrm{Al}$, $\mathrm{Si}, \mathrm{C}$, and $\mathrm{Fe}$ were at levels higher than $1 \%$. Fe levels were high in EFK 18.2 (3.49\%) and EFK 11.2 (1.97\%) (Egbo et al. 2017; Dickson et al. 2019), which might 
influence $\mathrm{Hg}$ bioavailability and the potential role of $\mathrm{Hg}$ methylators among the iron-reducing bacteria (IRB) in these sites. Targeted sampling of the HRD layer was conducted at EFK 18.2, which is known to contain high THg concentrations. Overall, THg levels were much higher in HRD soil at EFK $18.2(232.9-695.9 \mu \mathrm{g} / \mathrm{g})$ compared to EFK $11.2(3.3-54.5 \mu \mathrm{g} / \mathrm{g})$ and the reference site (HC) (0.03-0.04 $\mu \mathrm{g} / \mathrm{g})$. The HRD represents a distinct layer in streambank soils, which is dark gray to black in appearance due to the presence of coal fines and ash resulting in higher total carbon (TC) and organic carbon (OC) contents compared to EFK 11.2 and the reference site (Table 1), which may impact microbial community composition and the bioavailability of inorganic $\mathrm{Hg}$ for methylation.

Seasonal variations in $\mathrm{THg}$ levels were observed for both EFPC sampling sites. For site EFK 18.2, THg was highest in the fall followed by the summer, while in EFK 11.2, the highest $\mathrm{THg}$ was in the winter followed by the spring (Fig. 2a). MeHg in EFK 18.2 was highest in the winter sample $(12.7 \pm 0.6 \mathrm{ng} / \mathrm{g})$ and lowest in the fall $(4.7 \pm 0.2 \mathrm{ng} / \mathrm{g})$. In contrast, MeHg in EFK 11.2 was highest in the spring $(3.4 \pm 0.1 \mathrm{ng} / \mathrm{g})$, and the lowest in the fall $(0.15 \pm 0.008 \mathrm{ng} / \mathrm{g})$ (Fig. 2b). Generally, MeHg levels did not correlate with THg levels. The observed seasonal variations in $\mathrm{THg}$ and $\mathrm{MeHg}$ at each site are likely a result of heterogeneities within the soil layers and the area sampled.

\subsection{Microbial Community Characterization}

\subsubsection{Soil Microbiome}

Microorganisms can have a significant impact on net $\mathrm{MeHg}$ concentrations. Microbial community composition, as well as bioavailability of inorganic and organic $\mathrm{Hg}$ species, influences the relative contributions of microbial methylation and demethylation processes to net $\mathrm{Hg}$ methylation, which also depend on environmental conditions, such as geochemistry, temperature, and $\mathrm{pH}$ (Bratkič et al. 2017; Han et al. 2007; Bigham et al. 2017; Hsu-Kim et al. 2013). Methylation of mercury has been observed across a wide range of microbial clades, mainly within the $\delta$ Proteobacteria and Clostridia, in addition to a few members among the Chloroflexi, Bacteroidetes, methanogenic archaea, and others (Parks et al. 2013; Podar et al. 2015). Some strains within these clades were confirmed as $\mathrm{Hg}$ methylators (Gilmour et al. 2013; Gilmour et al. 2018), while others are predicted to methylate $\mathrm{Hg}$ based on harboring $h g c A B$ genes and are awaiting experimental confirmation. Overall, 16S rRNA sequence analysis showed that the soil microbial community across all samples consisted of 22 bacterial and 3 archaeal phyla, including Proteobacteria (ranging from 15.6 to $41.8 \%$ per sample), Acidobacteria (17.4-35.6\%), Nitrospirae (4.2 to $14 \%$ ), Actinobacteria (2.7 to $13.3 \%$ ), Chloroflexi (3.6 to 10.1), Verrucomicrobia (0.3 to 8.3\%), Cyanobacteria (0.1$7.1 \%)$, Bacteroidetes (0.1 to $6.2 \%)$, Firmicutes $(0.1$ to $1.5 \%$ ), Euryarchaeota ( 0.0 to $0.6 \%$ ), and few unclassified bacteria. Among those associated with $\mathrm{Hg}$ methylation, five bacterial clades have been identified across different seasons and sites. Figure $3 \mathrm{a}$ and Table 2 show predominant clades and associated with $\mathrm{Hg}$ methylation present at the studied sites. Throughout the year, Proteobacteria were the dominant clade (25.6\%), followed by Nitrospirae (10.1\%), Chloroflexi (6.5\%), Bacteroidetes (1.9\%), and Firmicutes $(0.4 \%)$. Three classes of bacteria associated with $\mathrm{Hg}$ methylation were predominant at the contaminated sites with relative abundances of $7.2 \%$ for the $\delta$-Proteobacteria (28.1\% of total Proteobacteria), Nitrospira 5.9\% (58.4\% of Nitrospirae), and Anaerolinea $1.8 \%$ (27.7\% of Chloroflexi). Among the $\delta$-Proteobacteria, two families, the Syntrophobacteraceae (SRB) and Geobacteraceae (IRB), were predominant particularly during the fall and spring with relative abundances of $4.0 \%$ and $0.13 \%$ (55.6\% and $1.8 \%$ of total $\delta$-Proteobacteria), respectively. Furthermore, the 16S rRNA gene amplicon sequencing data confirmed seasonal- and site-dependent abundance variations in clades associated with $\mathrm{Hg}$ methylation. The abundance of Chloroflexi was significantly $(P<0.05)$ higher during the summer, while no site-specific differences were observed. However, throughout the year, both Firmicutes and Proteobacteria were significantly $(P<0.05)$ higher in EFK 18.2 compared to EFK 11.2 and the control

Table 1 Contaminated soil physicochemical characteristics; $E F K$, East Fork kilometer; $g d w$, grams dry weight

\begin{tabular}{|c|c|c|c|c|c|c|c|c|}
\hline Site ID & $\%$ gravel & $\%$ sand & $\%$ silt & $\%$ clay & $\%$ moisture & $\mathrm{THg}(\mu \mathrm{g} / \mathrm{gdw})$ & $\mathrm{MeHg}(\mathrm{ng} / \mathrm{gdw})$ & $\mathrm{pH}$ \\
\hline EFK 18.2 & 1.6 & 31.4 & 50.1 & 16.9 & 22.50 & $232.9-689.5$ & $4.72-12.7$ & 7.8 \\
\hline EFK 11.2 & 0.0 & 22.1 & 56.1 & 21.8 & 21.61 & $3.32-54.50$ & $0.1-3.38$ & 7.4 \\
\hline
\end{tabular}




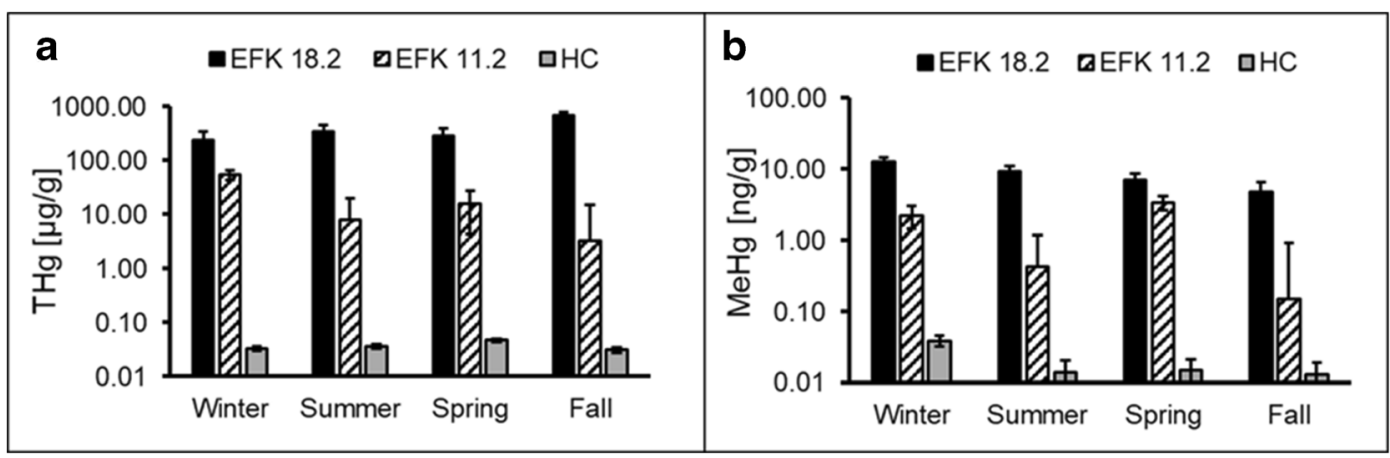

Fig. 2 Seasonal variation of $\mathbf{a} \mathrm{THg}$ and $\mathbf{b} \mathrm{MeHg}$ in EFPC streambank soils. EFK, East Fork kilometer; HC, Hinds Creek

site, while Bacteroidetes were significantly more abundant in EFK 11.2 (Fig. 3b). Furthermore, the Firmicutes were significantly $(P<0.05)$ higher in fall and winter relative to the other seasons, while the Proteobacteria showed no seasonal variation $(P>0.05)$. At the class level, the Anaerolinea class among the Chloroflexi was significantly more abundant $(P<0.05)$ in EFK 11.2 compared to EFK 18.2 and the control site and during the fall compared to other seasons, while the $\delta$-Proteobacteria were significantly more abundant $(P<0.05)$ in EFK 18.2 without seasonal variation. At the family level, the Geobacteraceae were significantly more abundant $(P<0.05)$ in the fall in both $\mathrm{Hg}$-contaminated sites compared to the uncontaminated control site. In contrast, the Syntrophobacteraceae were not statistically $(P>0.05)$ different among sites and seasons (Fig. 3c, d). Two genera, Geobacter and Nitrospira,

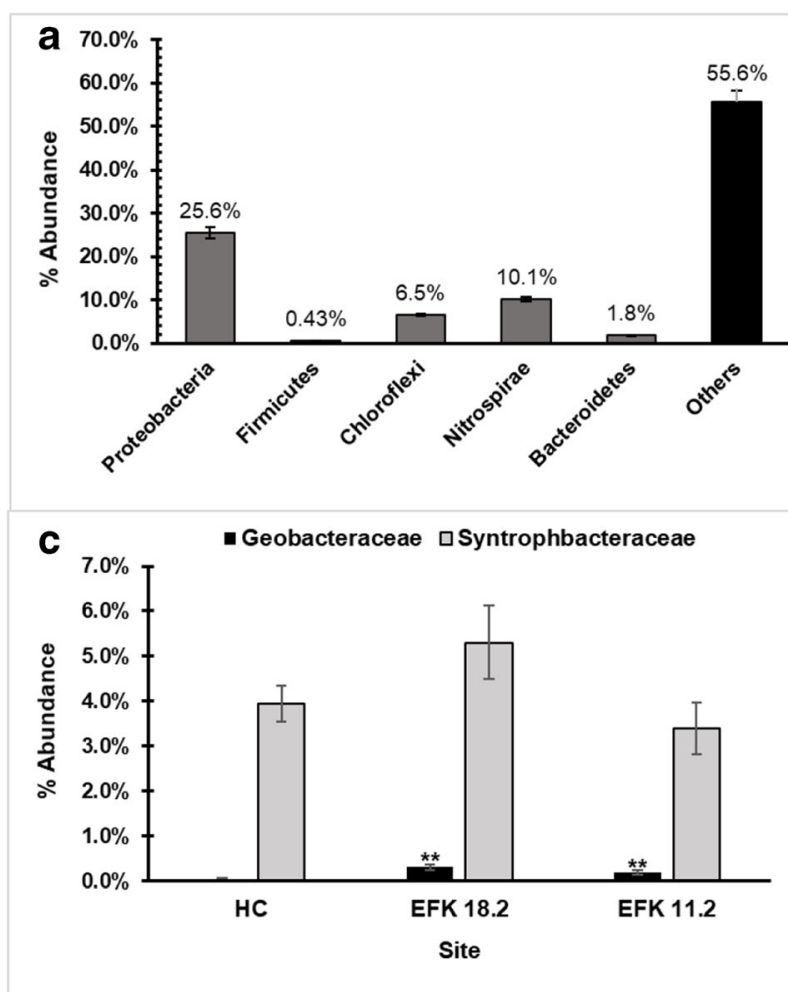

Fig. 3 Percentage abundances of microbial clades associated with $\mathrm{Hg}$ methylation in bank soil samples. a Average abundances of major bacterial clades across all sites and seasons. b Differences between clade abundances associated with $\mathrm{Hg}$ methylation across sites. c Site and d seasonal abundance variations of bacterial

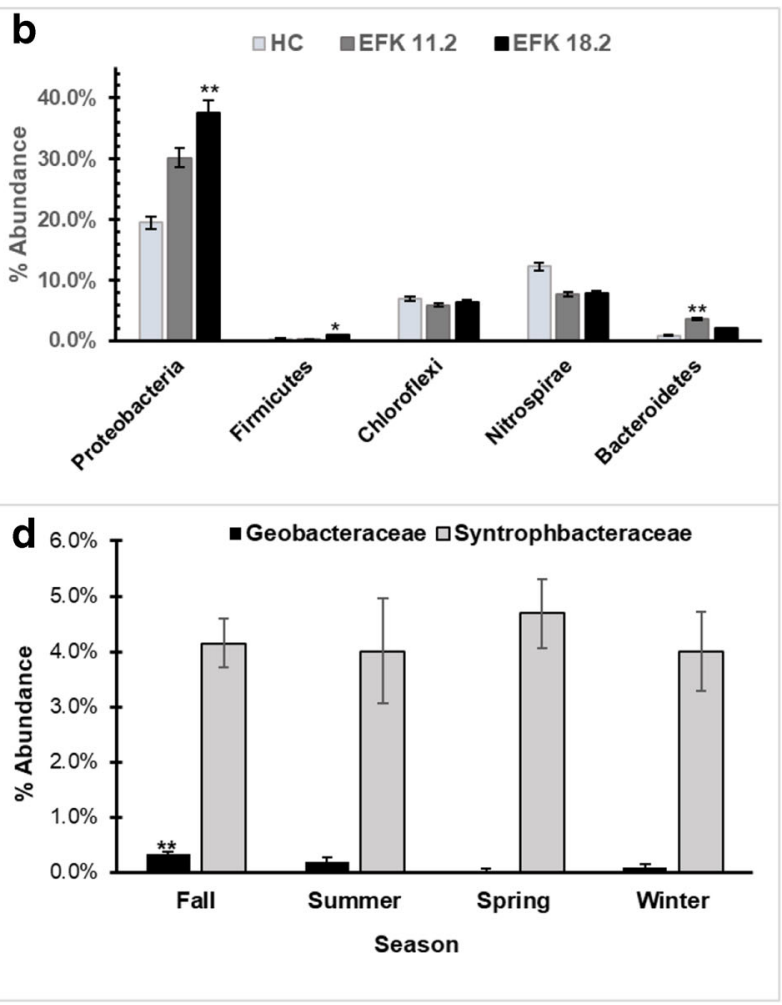

families in soil, EFK (East Fork kilometer). Percentage values represent the number of reads assigned to these OTUs relative to the number of reads across all OTUs in 26 samples from all sites and seasons 
were detected in the soils with relative abundances of $0.2 \%$ and $1.4 \%$, respectively. The genus Geobacter was detected in the fall samples only. It was significantly more abundant $(P<0.05)$ in Hg-contaminated sites compared to the uncontaminated control site. In contrast, Nitrospira were detected in all samples and were significantly more abundant in EFK 11.2 and during the fall season compared to the other sites and seasons (Table 2).

\subsubsection{Enrichment Cultures}

Soil enrichment cultures favored the growth of Firmicutes over Proteobacteria for samples collected across all seasons and sites except for the winter and summer samples collected from EFK 18.2. Out of the 11 bacterial and 2 archaeal phyla found in enrichment cultures, four bacterial and one methanogenic archaeal phyla were associated with $\mathrm{Hg}$ methylation with seasonal- and site-specific variations. Firmicutes dominated in the soil enrichment cultures with a relative abundance of $73 \%$, followed by Proteobacteria to a level almost equal to that found in soil samples (24.2\%), followed by Bacteroidetes $(0.28 \%)$, and Chloroflexi by $0.1 \%$ (Fig. 4a). When comparing seasonal differences in enrichment cultures, Firmicutes were significantly more abundant $(P<0.05)$ in the soil enrichments of summer and winter samples from the $\mathrm{HC}$ reference (control) site, and the spring and fall samples from EFK 18.2, while no seasonal variation was observed for samples from EFK 11.2. Both Bacteroidetes and Chloroflexi were significantly more abundant $(P<0.05)$ in soil enrichments of the winter and the spring samples from EFK 11.2 compared to all other sites and seasons. The Proteobacteria were significantly more abundant in enrichment cultures of summer and winter samples from EFK 18.2 and the fall samples from the control site when compared to the other seasons across the different sites.

At the class level, the Clostridia dominated by $43.0 \%$ in soil enrichments compared to $0.27 \%$ for each $\delta$ Proteobacteria and Bacteroidia. A comparison among sites showed that Clostridia were significantly more abundant $(P<0.05)$ in the enrichment cultures using soils from the control site with a relative abundance of $61.4 \%$ compared to $36.2 \%$ and $25.9 \%$ for soil samples from EFK 11.2 and EFK 18.2, respectively, while the abundance of the $\delta$-Proteobacteria was higher in samples collected from EFK 11.2 (0.47\%), compared to $0.2 \%$ in soils from both the control and EFK 18.2 site, but the difference was statistically insignificant.

For those associated with $\mathrm{Hg}$ methylation, five families among the Clostridia and two among the $\delta$-Proteobacteria were found in soil enrichments across different seasons and sites. Clostridiaceae, Peptococcaceae, Ruminococcaceae, Syntrophomonadaceae, and Veillonellaceae were predominant among the Clostridia with relative abundances of $6.3 \%, 1.8 \%, 2.0 \%, 0.13 \%$, and $15.2 \%$, respectively. Geobacteraceae and Syntrophobacteraceae were predominant among the $\delta$ Proteobacteria with a relative abundance of $0.1 \%$ each (Fig. 4b). The family of Desulfovibrionaceae among the $\delta$-Proteobacteria was detected with a relative abundance of $0.4 \%$ in the EFK 11.2 fall sample enrichment culture only, while it was not identified in soil isolates.

Table 2 Average percent abundances for 26 bank soil samples across all seasons and study sites

\begin{tabular}{llll}
\hline Clade & \% EFK 18.2 & $\%$ EFK 11.2 & \% Hinds Creek \\
\hline Proteobacteria & $36.5 \pm 1.48^{\mathrm{A}}$ & $29.6 \pm 1.04^{\mathrm{B}}$ & $19.0 \pm 0.74^{\mathrm{C}}$ \\
Firmicutes & $0.9 \pm 0.10^{\mathrm{A}}$ & $0.3 \pm 0.07^{\mathrm{B}}$ & $0.3 \pm 0.05^{\mathrm{B}}$ \\
Bacteroidetes & $2.1 \pm 0.67^{\mathrm{B}}$ & $3.5 \pm 0.61^{\mathrm{A}}$ & $0.9 \pm 0.09^{\mathrm{C}}$ \\
Chloroflexi & $6.8 \pm 0.48^{\mathrm{A}}$ & $6.8 \pm 0.33^{\mathrm{A}}$ & $6.8 \pm 0.24^{\mathrm{A}}$ \\
Nitrospirae & $7.9 \pm 1.33^{\mathrm{B}}$ & $7.6 \pm 0.73^{\mathrm{B}}$ & $12.2 \pm 0.32^{\mathrm{A}}$ \\
S-Proteobacteria & $8.5 \pm 0.76^{\mathrm{A}}$ & $7.4 \pm 0.54^{\mathrm{AB}}$ & $6.4 \pm 0.38^{\mathrm{B}}$ \\
Anaerolinea & $1.6 \pm 0.31^{\mathrm{AB}}$ & $2.4 \pm 0.22^{\mathrm{A}}$ & $1.2 \pm 0.15^{\mathrm{B}}$ \\
Geobacteraceae & $0.3 \pm 0.07^{\mathrm{A}}$ & $0.2 \pm 0.05^{\mathrm{A}}$ & $0.03 \pm 0.03^{\mathrm{B}}$ \\
Syntrophobacteraceae & $5.3 \pm 0.82^{\mathrm{A}}$ & $3.4 \pm 0.57^{\mathrm{A}}$ & $3.9 \pm 0.41^{\mathrm{A}}$ \\
Geobacter & $0.53 \pm 0.03^{\mathrm{A}}$ & $0.50 \pm 0.06^{\mathrm{A}}$ & $0.1 \pm 0.02^{\mathrm{B}}$ \\
Nitrospira & $1.3 \pm 0.28^{\mathrm{AB}}$ & $1.6 \pm 0.74^{\mathrm{A}}$ & $1.2 \pm 0.10^{\mathrm{B}}$
\end{tabular}

The letters A, B, and C indicate statistical significance among sites with $\mathrm{A}$ is the most abundant and $\mathrm{C}$ is the least abundant 

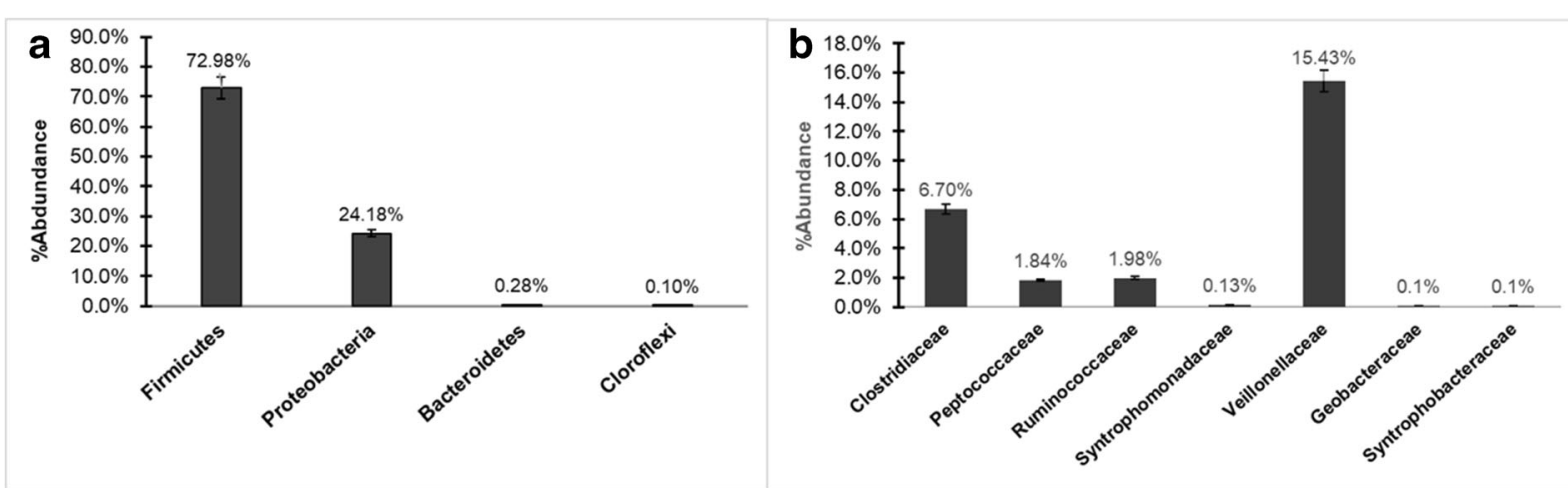

Fig. 4 Microbial community composition in enrichment cultures as average percentage abundances at a the phylum and $\mathbf{b}$ the family level

At the genus level, five genera, Geobacter, Clostridium, Alkaliphilus, Acetonema, and Desulfosporosinus, were detected in different soil enrichments. Variation in abundance between sampling sites was observed for Clostridium and Desulfosporosinus only, and both genera were significantly more abundant $(P<0.05)$ in enrichments from spring samples. Among soil enrichments Clostridium and Desulfosporosinus were among the top ten genera in soil enrichments from the $\mathrm{HC}$ reference site and EFK 18.2 with relative abundances of $2.6 \%$ and $1.7 \%$, respectively.

\subsubsection{Methanomicrobia in Enrichment Cultures}

The Methanomicrobia are a class of microorganisms among the Euryarchaeota associated with Hg methylation. Representatives of this class were detected in enriched soil cultures from $\mathrm{Hg}$-contaminated sites in winter and spring samples, with a relative abundance of $0.6 \%$. Specifically, the Methanomicrobiaceae were identified with an abundance of 5.8\% in the soil enrichment from EFK 11.2 collected in the spring, while the Methanocellaceae were found with an abundance of $0.6 \%$ in the soil enrichment of the winter sample from EFK 18.2. The Methanosarcinaceae were also identified in enrichments of the winter sample from EFK 18.2 (4.2\%), the winter and the spring samples from EFK 11.2 (5.6 and $0.1 \%$, respectively) and the fall sample from the HC reference site $(2.3 \%$ ) (Fig. 5a). Two genera, Methanocella and Methanosarcina, were identified in enrichment cultures with the winter samples from the Hg-contaminated sites. The genus Methanocella was identified in the winter samples from EFK 18.2 with a relative abundance of $0.6 \%$. In comparison, the genus Methanosarcina was found in both EFK 18.2 and EFK 11.2 in the winter samples with relative abundances of $3.2 \%$ and $5.6 \%$, respectively. In addition, Methanosarcina was also present in enrichment of the fall sample from the $\mathrm{HC}$ reference site. (Fig. 5b).

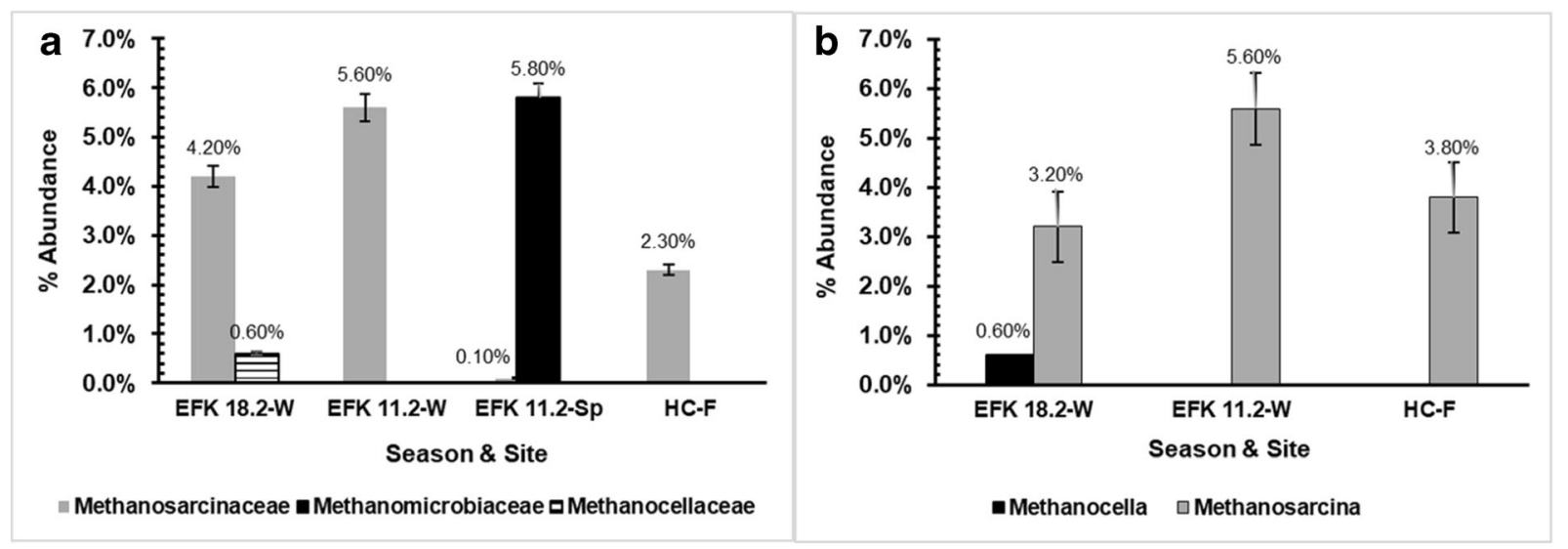

Fig. 5 Percentage abundances in enrichment cultures for a families and b genera among the Euryarchaeota; W, Winter; F, Fall; Sp, Spring; $\mathrm{HC}$, control 
3.3 Detection of $h g c A$-Biomarkers in Streambank Soils Using Primers

PCR amplification with the primers designed to target homologs of the $h_{g c A}$ gene produced a product of $\sim$ $950 \mathrm{bp}$. The three target strains were selected based on the families' abundance determined in the soil sequencing and to represent major groups of potential $\mathrm{Hg}$ methylators. Their primers are expected to hybridize with $h g c A$ variants from multiple species due to a high degree of sequence conservation among $h g c A$ genes. The product was successfully amplified from a total of 13 soils and enriched soils $(54.2 \%)$ from the 24 tested samples (Table 3). Amplicons corresponding to the expected size were recovered, purified, and sequenced. When $h g c A$ primers for $D$. desulfuricans ND132 were used, two soils and four enriched soils were found to be positive for $h g c A$ (EFK 18.2-winter and summer enriched soils; EFK 11.2-spring and fall for both soil and enriched soil samples) (Fig. 6a). Using primers targeting hgcA from G. sulfurreducens PCA, homologs were detected in soil samples from EFK 18.2 during winter, fall, and summer. With primers targeting $h g c A$ from D. tiedjei DCB-1, four samples were found positive, two in EFK 18.2 soils (winter and summer), and two in enriched soils from EFK 11.2 (summer and spring) (Fig. 6b). The recovered and sequenced amplicons were aligned to the $h g c A$ sequence of the corresponding target

Table 3 Sanger sequencing result of recovered bands and amplicons of expected positive soil and enriched soil samples. The first letter of the sample ID indicates culture (C) or soil (S); followed by season Spring (Sp.); Fall (F.); Winter (W.); Summer strain using the NCBI BLASTN tools and matched with significant $e$-values (Table 3 ).

\section{Discussion}

The goal of this study was to evaluate potential impacts of THg levels on the microbial community structures and to detect clades associated with $\mathrm{Hg}$ methylation in bank soils of a Hg-contaminated creek. Two contaminated bank soils, one with high THg levels and another one with lower levels, were compared to evaluate differences in the abundance of microbial clades associated with $\mathrm{Hg}$ methylation. In addition, samples collected across four seasons were compared to assess seasonal variations in the microbial soil community. In general, our results indicated that EFPC streambank soils contain several microbial clades that have been associated with $\mathrm{Hg}$ methylation, and their abundances in most cases were significant in one or both $\mathrm{Hg}$-contaminated sites compared to the control in different seasons (Table 2). A previous study conducted with EFPC stream sediments has shown significant correlations between the bacterial community and seasonal as well as geochemical factors, where some community members including SRB were associated positively with $\mathrm{THg}$ and $\mathrm{MeHg}$ concentrations (Vishnivetskaya et al. 2011). Other studies have shown seasonal effects on the biotic production of

(S.); followed by sampling site location EFK (East Fork kilometer). The letters at the end of the sample ID indicate the strainspecific primers used (ND132, PCA or DCB-1)

\begin{tabular}{|c|c|c|c|c|c|c|}
\hline$\#$ & Sample ID & Sanger sequence & Translation/motif & Seq. position & Blast position & $E$-value \\
\hline 1 & C.Sp.EFK11.2. ND & AACGTCTGGTGCGCGGCGGGAAAG & NVWCAAGK & $328-352$ & $267-287$ & $9 \mathrm{e}-07$ \\
\hline 2 & S.Sp.EFK11.2. ND & AACGTCTGGTGCGCGGCGGGA & NVWCAAG & $305-325$ & $268-276$ & $1 \mathrm{e}-08$ \\
\hline 3 & C.F.EFK11.2. ND & ACGTCTGGTGCGCGGCGGGA & NVWCAAG & $230-250$ & $268-287$ & $5 e-08$ \\
\hline 4 & S.F.EFK11.2. ND & AACGTCTGGTGCGCGGCG & NVWCAA & $70-91$ & $268-285$ & $2 \mathrm{e}-07$ \\
\hline 5 & C.W.EFK18.2. ND & AACGTCTGGTGCGCGGCGGGA & NVWCAAG & $109-129$ & $268-287$ & $1 \mathrm{e}-08$ \\
\hline 6 & C.S.EFK18.2. ND & AACGTCTGGTGCGCGGCCGGAAAG & NVWCAAGK & $327-350$ & $268-284$ & $9 \mathrm{e}-07$ \\
\hline 7 & S.S.EFK18.2. PCA & AATGTCTGGTGCGCCGCCGGA & NVWCAAG & $65-85$ & $235-254$ & $1 \mathrm{e}-08$ \\
\hline 8 & S.W.EFK18.2. PCA & AATGTCTGGTGCGCCGCCGGG & NVWCAAG & $761-781$ & $235-254$ & $1 \mathrm{e}-08$ \\
\hline 9 & S.F.EFK18.2. PCA & AATGTCTGGTGCGCCGCCGGA & NVWCAAG & $54-74$ & $235-254$ & $1 \mathrm{e}^{-}-08$ \\
\hline 10 & S.S.EFK18.2. DCB & AATGTCTGGTGTGCCAGCGGGA & NVWCAAG & $763-783$ & $256-269$ & $5 e-05$ \\
\hline 11 & C.S.EFK11.2. DCB & AATGTCTGGTGTGCAGCGGGC & NVWCAAG & $59-79$ & $256-275$ & $1 \mathrm{e}-08$ \\
\hline 12 & C.Sp.EFK11.2. DCB & AATGTCTGGTGTGCAGCGGGC & NVWCAAG & $220-240$ & $256-275$ & $1 \mathrm{e}-08$ \\
\hline 13 & S.W.EFK18.2. DCB & AATGTCTGGTGTGCAGCTGGTAAA & NVWCAAGK & $453-476$ & $256-272$ & $9 \mathrm{e}-07$ \\
\hline
\end{tabular}



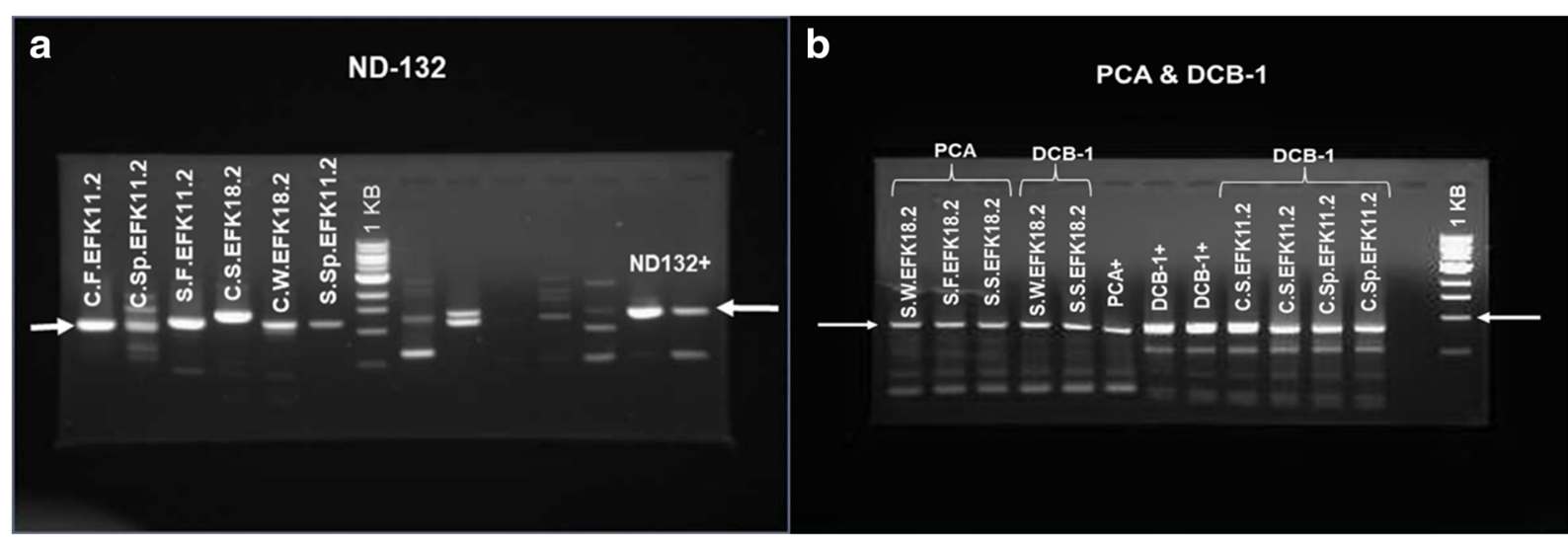

Fig. 6 PCR results using $h g c A$ primers, a $D$. desulfuricans (ND132) primers, b G. sulfurreducens (PCA), and D. tiedjei (DCB-1) primers. The first letter of the sample ID indicates culture (C) or

soil (S), followed by season Spring (Sp.); Fall (F.); Winter (W.); Summer (S.); followed by sampling site location EFK (East Fork kilometer)

$\mathrm{MeHg}$, with the highest levels linked to increased microbial activities during the summer months (Gilmour and Henry 1991; Stoichev et al. 2004).

Overall, the average fraction of $\mathrm{MeHg}$ was lower in EFK 18.2 compared to EFK 11.2 (2.2\% vs. 7.6\% $\mathrm{MeHg} / \mathrm{THg}$ ) and in all seasons except winter, which could be attributed to $\mathrm{Hg}$ bioavailability and differences in the microbial activity. In addition to microbial activity, soil constituents and geochemistry determine $\mathrm{Hg}$ speciation and its fate in the environment under various conditions (Bratkič et al. 2017; Han et al. 2007; Bigham et al. 2017; Ma et al. 2019). In aquatic systems containing low levels of sulfide, such as EFPC, $\mathrm{Hg}$ speciation is controlled to a large extend by complexation with natural organic matter (NOM) (Aiken et al. 2011). In addition, $\mathrm{pH}$, soil particle distributions, and redox conditions exert a substantial influence on $\mathrm{Hg}$ speciation, release, and bioavailability in EFPC (Egbo et al. 2017; Dickson et al. 2019). For example, the soil texture of the streambank soils along EFPC has been classified as loam and silty loam with the silt content decreasing with EFK distance (Dickson et al. 2017). The soil texture of the soils used in this study is silty clay loam (Egbo et al. 2017; Dickson et al. 2019), with a higher silt and clay content in EFK 11.2. Generally, higher Hg levels in the soil are associated with the finest size fractions, which can be explained by high specific surface area of clays to sorb Hg and NOM (Coufalík et al. 2012). Also, clays can form stable complexes with $\mathrm{Hg}$ depending on soil geochemistry (Liao et al. 2009; Biester et al. 2002; Boszke et al. 2008), which may decrease Hg leachability, bioavailability, and consequently $\mathrm{MeHg}$ levels. While the clay content in bank soils at EFK 18.2 is

lower compared to EFK 11.2, the Hg level is higher, which has attributed to the inclusion of $\mathrm{Hg}$ in coal fines and ash in the HRD layer at this site. Due to the higher carbon and NOM contents, as demonstrated by other studies (Bigham et al. 2017; Hsu-Kim et al. 2013; Różański et al. 2016; Beckers and Rinklebe 2017), the interaction of the $\mathrm{Hg}$ species with these soil constituents may control solubility and bioavailability for methylation. A study showed that elevated THg is often associated with organic-rich soil as $\mathrm{Hg}$ has a high affinity to thiol functional groups present in NOM (Beckers and Rinklebe 2017). Also, it was shown that soil organic carbon might increase the fraction of mobile $\mathrm{Hg}$. In contrast, clay reduces the mobile fraction (Różański et al. 2016). Therefore, variations of the factors mentioned above in our study sites may play a critical role and contribute to differences in $\mathrm{THg}$ and $\mathrm{MeHg}$ levels.

Other geochemical factors can also exert a strong influence on $\mathrm{Hg}$ bioavailability and microbial activity. The growth and the activity of the potential methylators as well as any other microorganisms are influenced by the $\mathrm{pH}$. A high $\mathrm{pH}$ also reduces methylation potential by reducing $\mathrm{Hg}$ bioavailability. It was shown that a high $\mathrm{pH}$ increased $\mathrm{Hg}$ bound to Fe-Mn-oxides, thus lowering bioavailability and reducing methylation potential (Chen et al. 2016). Other studies demonstrated that $\mathrm{Hg}$ (II) leachability and bioavailability are highly affected by $\mathrm{pH}$ and increase under acidic conditions (Miretzky et al. 2005) (Coufalík et al. 2012; Gilmour and Henry 1991). On the other hand, the high level of Fe in EFK 18.2 soils (3.49\%) and to a lesser extent in EFK 11.2 soils $(1.97 \%)$ may create favorable redox conditions for IRB as evidenced by the presence of IRB at these sites. 
The elevated MeHg concentrations at EFK 18.2 may be a result of the biogeochemical soil characteristics leading to higher MeHg levels.

Several microbial community members, including SRB in EFPC sediments, were positively associated with $\mathrm{THg}$ and $\mathrm{MeHg}$ (Vishnivetskaya et al. 2011). In our results, we observed that about $44.4 \%$ of the microbial phyla in the EFPC streambank soils were from those being associated with $\mathrm{Hg}$ methylation (see Fig. $3 a$ ), and some of them were significantly more abundant in the Hg-contaminated sites compared to the control (Table 2). A comparison of the present data with a previously published study shows that the microbial communities in EFPC bank soils and creek sediments are almost identical (Vishnivetskaya et al. 2011). Similar relative abundances suggest a frequent exchange between bank soils and sediments due to bank erosion, flooding events, and runoff. A comparison of samples over four seasons did not show significant changes among the most abundant microbial clades. The Proteobacteria showed no seasonal variation, while Firmicutes were more abundant during the fall and winter and the Chloroflexi were the only clade that showed higher abundance in the summer compared to other seasons with no site preference. However, Proteobacteria and Firmicutes were higher in EFK 18.2. The large variability in the $\mathrm{MeHg}$ concentrations over different seasons and across sites was most likely a result of geochemical factors specific to each site that determine $\mathrm{Hg}$ speciation, bioavailability, and microbial activity. Interestingly, soil enrichment cultures promoted the growth of only $52 \%$ of the microbes identified in the respective soil. Firmicutes were enriched preferentially up to an abundance of $73 \%$.

Detection of the $h_{g c A B}$ genes and determining their abundance in Hg-contaminated environments is crucial for predicting active microbial $\mathrm{Hg}$ methylation. Using primers of strains that represent three major methylating clades, we were able to detect homologs of the key $h g c A$ gene in $54.2 \%$ of the EFPC streambank soil samples across all seasons. Amplicon sequencing and alignments showed that all positive samples could be matched to target strains closely related to $\mathrm{Hg}$ methylating species. Moreover, the abundance of the $\mathrm{Hg}$-methylating clades correlated with higher $\mathrm{MeHg}$ levels, and in samples where $h g c A$ was detected. Using ND132 $h g c A$ primers, homologs were detected at EFK 18.2 in winter and summer samples. With the PCA $h g c A$ primers, homologs were detected at EFK 18.2 only and in samples collected during the winter, fall, and summer. In contrast, with DCB-1 hgcA primers, homologs were detected at EFK 18.2 in winter and summer samples and EFK 11.2 in spring and summer samples. These results suggest a potential role for IRB and syntrophs in EFPC bank soils.

\section{Conclusions}

Microbial communities play an essential role in the transformation of $\mathrm{Hg}$ in contaminated watersheds. Net $\mathrm{MeHg}$ production is controlled by a complex interplay between biotic and abiotic factors. In this study, we investigated the role of the microbial community composition in contaminated bank soils in light of other biogeochemical factors, such as $\mathrm{Hg}$ concentration, soil composition, and chemistry. Overall, microbial clades associated with $\mathrm{Hg}$ methylation were found to be more abundant in Hg-contaminated soils, which is also in agreement with the distribution of detectable $h g c A$ genes in the soil. Thus, determining the microbial community structure and targeting genes linked to $\mathrm{Hg}$ methylation to identify potential methylators is crucial for informing mitigation efforts for Hg-contaminated sites.

Acknowledgments This research was supported by the US Department of Energy (DOE) and Savannah River Nuclear Solution (SRNS) under subcontract no. 0000403075 and in part by the US Department of Energy's (DOE) Oak Ridge Office of Environmental Management (ORO-EM) and URS | CH2M Oak Ridge LLC (UCOR) under the Mercury Remediation Technology Development Program at Oak Ridge National Laboratory (ORNL). ORNL is managed by UT-Battelle, LLC, for the US DOE under contract no. DE-AC05-00OR22725. We are grateful to Dr. Wendell McElhenney, at Tuskegee University for his generous help with statistical analyses.

Authors' Contributions All authors read and approved the final manuscript.Data AvailabilityThe authors confirm that the data supporting the findings of this study are available within the article.

Compliance with Ethical Standards

Conflict of Interest The authors declare that they have no conflict of interest.

Ethics Approval Not applicable - no animal or human participants.

Consent to Participate Not applicable - no animal or client participants. 
Consent for Publication Not applicable - no individual person's data in any form.

Code Availability Not applicable — no custom code required.

Open Access This article is licensed under a Creative Commons Attribution 4.0 International License, which permits use, sharing, adaptation, distribution and reproduction in any medium or format, as long as you give appropriate credit to the original author(s) and the source, provide a link to the Creative Commons licence, and indicate if changes were made. The images or other third party material in this article are included in the article's Creative Commons licence, unless indicated otherwise in a credit line to the material. If material is not included in the article's Creative Commons licence and your intended use is not permitted by statutory regulation or exceeds the permitted use, you will need to obtain permission directly from the copyright holder. To view a copy of this licence, visit http://creativecommons.org/licenses/by/4.0/.

\section{References}

Achá, D., Hintelmann, H., \& Yee, J. (2011). Importance of sulfate reducing bacteria in mercury methylation and demethylation in periphyton from Bolivian Amazon region. Chemosphere, 82(6), 911-916.

Achá, D., Hintelmann, H., \& Pabón, C. A. (2012). Sulfatereducing bacteria and mercury methylation in the water column of the lake 658 of the experimental lake area. Geomicrobiology Journal, 29(7), 667-674.

Aiken, G. R., Hsu-Kim, H., \& Ryan, J. N. (2011). Influence of dissolved organic matter on the environmental fate of metals, nanoparticles, and colloids. Environmental Science \& Technology, 45(8), 3196-3201. https://doi.org/10.1021 les103992s.

Bae, H.-S., Dierberg, F. E., \& Ogram, A. (2014). Syntrophs dominate sequences associated with the mercury methylation-related gene hgcA in the water conservation areas of the Florida Everglades. Applied and Environmental Microbiology, 80(20), 6517-6526.

Barnett, M., \& Turner, R. (1995). Bioavailability of mercury in East Fork Poplar Creek soils. Oak Ridge National Lab.

Barnett, M. O., Harris, L. A., Turner, R. R., Stevenson, R. J., Henson, T. J., Melton, R. C., et al. (1997). Formation of mercuric sulfide in soil. Environmental Science \& Technology, 31(11), 3037-3043.

Beckers, F., \& Rinklebe, J. (2017). Cycling of mercury in the environment: sources, fate, and human health implications: a review. Critical Reviews in Environmental Science and Technology, 47(9), 693-794.

Biester, H., Muller, G., \& Scholer, H. F. (2002). Binding and mobility of mercury in soils contaminated by emissions from chlor-alkali plants. Science of the Total Environment, 284(13), 191-203. https://doi.org/10.1016/s0048-9697(01)008853 .
Bigham, G. N., Murray, K. J., Masue-Slowey, Y., \& Henry, E. A. (2017). Biogeochemical controls on methylmercury in soils and sediments: implications for site management. Integrated Environmental Assessment and Management, 13(2), 249263. https://doi.org/10.1002/ieam.1822.

Boszke, L., Kowalski, A., Astel, A., Barański, A., Gworek, B., \& Siepak, J. (2008). Mercury mobility and bioavailability in soil from contaminated area. Environmental Geology, 55(5), 1075-1087.

Bratkič, A., Koron, N., Ribeiro Guevara, S., Faganeli, J., \& Horvat, M. (2017). Seasonal variation of mercury methylation potential in pristine coastal marine sediment from the Gulf of Trieste (northern Adriatic Sea). Geomicrobiology Journal, 34(7), 587-595.

Bravo, A. G., Bouchet, S., Guédron, S., Amouroux, D., Dominik, J., \& Zopfi, J. (2015). High methylmercury production under ferruginous conditions in sediments impacted by sewage treatment plant discharges. Water Research, 80, 245-255.

Bravo, A. G., Loizeau, J.-L., Dranguet, P., Makri, S., Björn, E., Ungureanu, V. G., et al. (2016). Persistent Hg contamination and occurrence of $\mathrm{Hg}$-methylating transcript (hgcA) downstream of a chlor-alkali plant in the Olt River (Romania). Environmental Science and Pollution Research, 23(11), 10529-10541.

Brooks, S. C., \& Southworth, G. R. (2011). History of mercury use and environmental contamination at the Oak Ridge Y-12 Plant. Environmental Pollution, 159(1), 219-228. https://doi.org/10.1016/j.envpol.2010.09.009.

Chen, X., Ji, H., Yang, W., Zhu, B., \& Ding, H. (2016). Speciation and distribution of mercury in soils around gold mines located upstream of Miyun Reservoir, Beijing, China. Journal of Geochemical Exploration, 163, 1-9.

Christensen, G. A., Wymore, A. M., King, A. J., Podar, M., Hurt Jr., R. A., Santillan, E. U., et al. (2016). Development and validation of broad-range qualitative and clade-specific quantitative molecular probes for assessing mercury methylation in the environment. Applied and Environmental Microbiology, 82(19), 6068-6078. https://doi.org/10.1128 /AEM.01271-16.

Christensen, G. A., Somenahally, A. C., Moberly, J. G., Miller, C. M., King, A. J., Gilmour, C. C., et al. (2018). Carbon amendments alter microbial community structure and net mercury methylation potential in sediments. Applied and Environmental Microbiology, 84(3). https://doi.org/10.1128 /AEM.01049-17.

Coppi, M. V., Leang, C., Sandler, S. J., \& Lovley, D. R. (2001). Development of a genetic system for Geobacter sulfurreducens. Applied and Environmental Microbiology, 67(7), 3180-3187. https://doi.org/10.1128/AEM.67.7.31803187.2001.

Coufalík, P., Krásenský, P., Dosbaba, M., \& Komárek, J. (2012). Sequential extraction and thermal desorption of mercury from contaminated soil and tailings from Mongolia. Central European Journal of Chemistry, 10(5), 1565-1573.

DeWeerd, K. A., Mandelco, L., Tanner, R. S., Woese, C. R., \& Suflita, J. M. (1990). Desulfomonile tiedjei gen. nov. and sp. nov., a novel anaerobic, dehalogenating, sulfate-reducing bacterium. Archives of Microbiology, 154(1), 23-30. https://doi.org/10.1007/BF00249173.

Dickson, J. O., Mayes, M., Earles, J. E., Mehlhorn, T. L., Lowe, K. A., Peterson, M. J., et al. (2017). Soil investigation of lower 
East Fork Poplar Creek. Oak Ridge: Oak Ridge National Lab.(ORNL).

Dickson, J. O., Mayes, M. A., Brooks, S. C., Mehlhorn, T. L., Lowe, K. A., Earles, J. K., et al. (2019). Source relationships between streambank soils and streambed sediments in a mercury-contaminated stream. Journal of Soils and Sediments, 19(4), 2007-2019.

Donovan, P. M., Blum, J. D., Demers, J. D., Gu, B., Brooks, S. C., \& Peryam, J. (2014). Identification of multiple mercury sources to stream sediments near Oak Ridge, TN, USA. Environmental Science \& Technology, 48(7), 3666-3674. https://doi.org/10.1021/es4046549.

Egbo, T. E., Dickson, J. O., Miller, C., Johs, A., Sanders, C. A., \& Robertson, B. K. (2017). Characterization, identification and seasonal evaluation of microbes in mercury contaminated soils. Frontiers in Science, Technology, Engineering and Mathematics, 1(1), 15-26.

Fleming, E. J., Mack, E. E., Green, P. G., \& Nelson, D. C. (2006). Mercury methylation from unexpected sources: molybdateinhibited freshwater sediments and an iron-reducing bacterium. Applied and Environmental Microbiology, 72(1), 457464.

Gilmour, C. C., \& Henry, E. A. (1991). Mercury methylation in aquatic systems affected by acid deposition. Environmental Pollution, 71(2-4), 131-169. https://doi.org/10.1016/02697491(91)90031-q.

Gilmour, C. C., Podar, M., Bullock, A. L., Graham, A. M., Brown, S. D., Somenahally, A. C., et al. (2013). Mercury methylation by novel microorganisms from new environments. Environmental Science \& Technology, 47(20), 1181011820. https://doi.org/10.1021/es403075t.

Gilmour, C. C., Bullock, A. L., McBurney, A., Podar, M., \& Elias, D. A. (2018). Robust mercury methylation across diverse methanogenic archaea. Mbio, 9(2). https://doi.org/10.1128 /mBio.02403-17.

Hamelin, S., Amyot, M., Barkay, T., Wang, Y., \& Planas, D. (2011). Methanogens: principal methylators of mercury in lake periphyton. Environmental Science \& Technology, 45(18), 7693-7700

Han, S., Obraztsova, A., Pretto, P., Choe, K. Y., Gieskes, J., Deheyn, D. D., et al. (2007). Biogeochemical factors affecting mercury methylation in sediments of the Venice Lagoon, Italy. Environmental Toxicology and Chemistry, 26(4), 655663. https://doi.org/10.1897/06-392r.1.

Harris, L., Henson, T., Combs, D., Melton, R., Steele, R., \& Marsh, G. (1996). Imaging and microanalyses of mercury in flood plain soils of East Fork Poplar Creek. Water, Air, and Soil Pollution, 86(1-4), 51-69.

Hintelmann, H. (2010). Organomercurials. Their formation and pathways in the environment. Metal Ions in Life Sciences, 7, 365-401. https://doi.org/10.1039/BK978184755177100365 .

Hsu-Kim, H., Kucharzyk, K. H., Zhang, T., \& Deshusses, M. A. (2013). Mechanisms regulating mercury bioavailability for methylating microorganisms in the aquatic environment: a critical review. Environmental Science \& Technology, 47(6), 2441-2456. https://doi.org/10.1021/es304370g.

Ketelle, R., Brandt, C. C., Peterson, M. J., Bevelhimer, M. S., Watson, D. B., Brooks, S. C., et al. (2017). Evaluation of lower East Fork Poplar Creek mercury sources-model update. Oak Ridge National Laboratory (ORNL).
Kozich, J. J., Westcott, S. L., Baxter, N. T., Highlander, S. K., \& Schloss, P. D. (2013). Development of a dual-index sequencing strategy and curation pipeline for analyzing amplicon sequence data on the MiSeq Illumina sequencing platform. Applied and Environmental Microbiology, 79(17), 51125120. https://doi.org/10.1128/AEM.01043-13.

Kumar, R., Eipers, P., Little, R. B., Crowley, M., Crossman, D. K., Lefkowitz, E. J., et al. (2014). Getting started with microbiome analysis: sample acquisition to bioinformatics. Current Protocols in Human Genetics, 82(1), 1818 11-18 18 29. https://doi.org/10.1002/0471142905.hg1808s82.

Liao, L., Selim, H. M., \& Delaune, R. D. (2009). Mercury adsorption-desorption and transport in soils. Journal of Environmental Quality, 38(4), 1608-1616. https://doi. org/10.2134/jeq2008.0343.

Lin, H., Morrell-Falvey, J. L., Rao, B., Liang, L., \& Gu, B. (2014). Coupled mercury-cell sorption, reduction, and oxidation on methylmercury production by Geobacter sulfurreducens PCA. Environmental Science \& Technology, 48(20), 11969-11976. https://doi.org/10.1021/es502537a.

Ma, M., Du, H., \& Wang, D. (2019). Mercury methylation by anaerobic microorganisms: A review. Critical Reviews in Environmental Science and Technology, 49(20), 1893-1936.

McDonald, D., Price, M. N., Goodrich, J., Nawrocki, E. P., DeSantis, T. Z., Probst, A., et al. (2012). An improved Greengenes taxonomy with explicit ranks for ecological and evolutionary analyses of bacteria and archaea. ISME Journal, 6(3), 610-618. https://doi.org/10.1038 /ismej.2011.139.

Miretzky, P., Bisinoti, M. C., Jardim, W. F., \& Rocha, J. C. (2005). Factors affecting $\mathrm{Hg}$ (II) adsorption in soils from the Rio Negro basin (Amazon). Química Nova, 28(3), 438-443.

Mohn, W. W., \& Tiedje, J. M. (1991). Evidence for chemiosmotic coupling of reductive dechlorination and ATP synthesis in Desulfomonile tiedjei. Archives of Microbiology, 157(1), 1-6.

Pak, K.-R., \& Bartha, R. (1998). Mercury methylation and demethylation in anoxic lake sediments and by strictly anaerobic bacteria. Applied and Environmental Microbiology, 64(3), 1013-1017.

Parks, J. M., Johs, A., Podar, M., Bridou, R., Hurt Jr., R. A., Smith, S. D., et al. (2013). The genetic basis for bacterial mercury methylation. Science, 339(6125), 1332-1335. https://doi. org/10.1126/science. 1230667.

Podar, M., Gilmour, C. C., Brandt, C. C., Soren, A., Brown, S. D., Crable, B. R., et al. (2015). Global prevalence and distribution of genes and microorganisms involved in mercury methylation. Science Advances, 1(9), e1500675. https://doi. org/10.1126/sciadv.1500675.

Revis, N., Osborne, T., Holdsworth, G., \& Hadden, C. (1989). Distribution of mercury species in soil from a mercurycontaminated site. Water, Air, and Soil Pollution, 45(1-2), 105-113.

Riscassi, A., Miller, C., \& Brooks, S. (2016). Seasonal and flowdriven dynamics of particulate and dissolved mercury and methylmercury in a stream impacted by an industrial mercury source. Environmental Toxicology and Chemistry, 35(6), 1386-1400. https://doi.org/10.1002/etc.3310.

Różański, S. Ł., Castejón, J. M. P., \& Fernández, G. G. (2016). Bioavailability and mobility of mercury in selected soil profiles. Environmental Earth Sciences, 75(13), 1065. 
Saxton, A. (1998). A macro for converting mean separation output to letter groupings in Proc Mixed. Proceedings of the 23rd SAS Users Group International, 22-25 Mar 1998, Nashville, 1243-1246.

Southworth, G. R., Greeley, M., Peterson, M., Lowe, K., \& Ketelle, R. H. (2010). Sources of mercury to East Fork Poplar Creek downstream from the Y-12 national security complex: inventories and export rates. ORNL/TM-2009/231. Oak Ridge: Oak Ridge National Laboratory.

Southworth, G., Mathews, T., Greeley, M., Peterson, M., Brooks, S., \& Ketelle, D. (2013). Sources of mercury in a contaminated stream-implications for the timescale of recovery. Environmental Toxicology and Chemistry, 32(4), 764-772. https://doi.org/10.1002/etc. 2115.

Stoichev, T., Amouroux, D., Wasserman, J., Point, D., De Diego, A., Bareille, G., et al. (2004). Dynamics of mercury species in surface sediments of a macrotidal estuarine-coastal system (Adour River, Bay of Biscay). Estuarine, Coastal and Shelf Science, 59(3), 511-521.

Tukey, J. W. (1949). Comparing individual means in the analysis of variance. Biometrics, 5(2), 99-114.

Turner, R. R., \& Southworth, G. R. (1999). Mercury-contaminated industrial and mining sites in North America: an overview with selected case studies. In Mercury contaminated sites. Environmental Science. (pp. 89-112). Springer, Berlin, Heidelberg. https://doi.org/10.1007/978-3-662-03754-6_4.

Vishnivetskaya, T. A., Mosher, J. J., Palumbo, A. V., Yang, Z. K., Podar, M., Brown, S. D., et al. (2011). Mercury and other heavy metals influence bacterial community structure in contaminated Tennessee streams. Applied and Environmental Microbiology, 77(1), 302-311. https://doi.org/10.1128 /AEM.01715-10.

Wang, Q., Garrity, G. M., Tiedje, J. M., \& Cole, J. R. (2007). Naive Bayesian classifier for rapid assignment of rRNA sequences into the new bacterial taxonomy. Applied and Environmental Microbiology, 73(16), 5261-5267. https://doi.org/10.1128/aem.00062-07.

Watson, D. B., Brooks, S. C., Mathews, T. J., Bevelhimer, M. S., DeRolph, C., Brandt, C. C., et al. (2016). Evaluation of lower East Fork Poplar Creek mercury sources. Oak Ridge National Lab.(ORNL).

Wolin, E. A., Wolin, M. J., \& Wolfe, R. S. (1963). Formation of methane by bacterial extracts. Journal of Biological Chemistry, 238(8), 2882-2886.

Zane, G. M., Yen, H. C., \& Wall, J. D. (2010). Effect of the deletion of qmoABC and the promoter-distal gene encoding a hypothetical protein on sulfate reduction in Desulfovibrio vulgaris Hildenborough. Applied and Environmental Microbiology, 76(16), 5500-5509. https://doi.org/10.1128 /AEM.00691-10.

Publisher's Note Springer Nature remains neutral with regard to jurisdictional claims in published maps and institutional affiliations. 